\title{
Hematological parameters of Hoplias malabaricus (Characiformes: Erythrinidae) parasitized by Monogenea in lagoons in Pirassununga, Brazil
}

\author{
Parâmetros hematológicos de Hoplias malabaricus (Characiformes: Erythrinidae) parasitados \\ por monogenea em lagoas de Pirassununga, Brasil \\ Lincoln Lima Corrêa ${ }^{1}$; Letícia Cucolo Karling'2; Ricardo Massato Takemoto²; \\ Paulo Sérgio Ceccarelli ${ }^{3}$; Marlene Tiduko Ueta ${ }^{1}$
}

\begin{abstract}
${ }^{1}$ Departamento de Biologia Animal, Instituto de Biologia - IB, Universidade Estadual de Campinas - UNICAMP, Campinas, SP, Brasil

${ }^{2}$ Laboratório de Ictioparasitologia, Núcleo de Pesquisas em Limnologia, Ictiologia e Aquicultura - NUPÉLIA, Universidade Estadual de Maringá - UEM, Maringá, PR, Brasil

${ }^{3}$ Centro Nacional de Pesquisa e Conservação de Peixes Continentais - CEPTA,

Instituto Chico Mendes de Conservaçáo da Biodiversidade - ICMBio, Pirassununga, SP, Brasil
\end{abstract}

Received January 07, 2013

Accepted April 18, 2013

\begin{abstract}
Hematology is an important pathological and diagnostic tool. This paper describes the hematological parameters of 76 specimens of Hoplias malabaricus infested with monogenean parasites, which were collected from two lagoons. The hematological parameters included: erythrocyte count $(\mathrm{Er})$, microhematocrit $(\mathrm{Hct})$, hemoglobin $(\mathrm{Hb})$, mean corpuscular volume $(\mathrm{MCV})$, mean corpuscular hemoglobin $(\mathrm{MCH})$ and mean corpuscular hemoglobin concentration $(\mathrm{MCHC})$. The blood parameters showed no significant changes associated with the infestation. Water temperature was found to be negatively correlated with MCV and Hct, with values of $r_{s}=-0.52, p<0.0001$ and $r_{s}=-0.48, p<0.0001$, respectively. The mean Relative Condition Factor was $\mathrm{Kn}=1.01$, indicating good health conditions of the fish in these lagoons. No correlation was found between the monogenean infestation and the blood parameters, or between the environmental factors and the monogeneans.
\end{abstract}

Keywords: Parasites, blood cells, freshwater fish.

\section{Resumo}

A hematologia é uma importante ferramenta para patologia e diagnóstico. O presente estudo teve como objetivo descrever os parâmetros hematológicos de 76 espécimes de Hoplias malabaricus, coletados em duas lagoas, associados ao parasitismo por monogenético. Os parâmetros hematológicos foram: contagem de eritrócitos (Er), micro hematócrito (Hct), hemoglobina (Hb), volume corpuscular médio (VCM), hemoglobina corpuscular (HCM) e a concentração da hemoglobina cospuscular média (CHCM). Observou-se que não ocorreram mudanças significativas nos parâmetros sanguíneos relacionados com o parasitismo. Houve uma correlação negativa entre a temperatura da água o VCM e Hct, com valores de $r_{s}=-0,52, p<0,0001$ e $r_{s}=-0,48, p<0,0001$, respectivamente. $\mathrm{O}$ valor médio entre o fator de condição relativo foi de $\mathrm{Kn}=1,01$, indicando boas condiçóes e os peixes estavam saudáveis nas lagoas estudadas. Não houve relação entre a infestação de monogeneas e os parâmetros sanguíneos, ou entre os fatores ambientais e as monogeneas.

Palavras-chave: Parasitas, células sanguíneas, peixes de água doce.

\footnotetext{
${ }^{*}$ Corresponding author: Lincoln Lima Corrêa

Departamento de Biologia Animal, Instituto de Biologia - IB, Universidade

Estadual de Campinas - UNICAMP, Cidade Universitária "Zeferino Vaz",

CP 6109, CEP 13083-862, Campinas, SP, Brasil

e-mail: lincorre@gmail.com; lincorre@hotmail.com

Financial support: CAPES
} 


\section{Introduction}

Studies of the hematological parameters of fish are important since they provide relevant information about the animals' physiological capacity (VILJOEN; VAN VUREN, 1991; BALLARIN et al., 2004; WELLS et al., 2005), serving as a useful tool to evaluate the immunologic system (BALLARIN et al., 2004; TAVARES-DIAS; MORAES, 2004, 2007). Hematocrit, hemoglobin concentration and red blood cell size values are important indicators of the oxygen transport capacity of water, oxygen removal rate, and oxygen availability for tissues (GRAHAM et al., 1985; TAVARESDIAS; MORAES, 2004; WELLS et al., 2005).

Hematological parameters can also provide information about the health of a given fish population, and are important indicators of changes in the environment or in the physiology of these animals (PAIVA et al., 2000a, b).

Studies have demonstrated that physiological alterations related to water quality, whether or not they are affected by pollution, are reflected in the values of one or more hematological parameters (VAN VUREN, 1986).

Hematological alterations in fish cultivated in Brazil have been characterized in Cyprinus carpio (PAIVA et al., 1997) and Piaractus mesopotamicus (TAVARES-DIAS et al., 1999a) infested by Argulus sp., in Mugil platanus infected by Trypanosoma sp., Haemogregarina, Trichodina, Monogenea, Copepods and Hirudinea (PAIVA et al., 1997); in Piaractus mesopotamicus and Leporinus macrocephalus infected by Monogenea, in Ichthyophthirius multifiliis, Trichodina sp., Piscinoodinium pillulare and Lernaea cyprinacea (TAVARES-DIAS et al., 1999b), in Oreochromis niloticus infected by Ichthyophthirius multifliis (TAVARES-DIAS et al., 2002), and in Hoplias malabaricus infected by L3 larvae of Contracaecum sp. (CORRÊA et al., 2013).

For fish parasitized by ectoparasites such as Monogenea, environmental changes can be reflected in reproduction, physiology, survival (KHAN; THULIN, 1991) and fish population size (MACKENZIE et al., 1995; MACKENZIE, 1999; MOLES; WADE, 2001; KHAN, 2003). Kohn et al. (2007) described the effect of Gyrodactylus trairae on the surface of the body and Urocleidoides eremitus on the gills of $H$. malabaricus. More recently, Rosim et al. (2011) described three new species of Urocleidoides on the gills of $H$. malabaricus (U. malabaricusi, $U$. cuiabai and $U$. brasiliensis) and in the nasal cavity (U. naris).

Hoplias malabaricus, a fish of the Erythrinidae family, is widely distributed in South America, except in the Andes region and in the rivers of Patagonia (NAKATANI et al., 2001). This carnivorous species feeds mainly on fish, lives in lentic waters, and possesses significant resistance to low levels of oxygen (SILVANO et al., 2001).

The purpose of this study was to analyze the hematological parameters of $H$. malabaricus, seeking to determine whether the epidemiological indices of Monogenea are correlated with the condition factor of the fish and with environmental factors.

\section{Materials and Methods}

Seventy-six specimens of $H$. malabaricus (BLOCH, 1794) were captured with gillnets in two lagoons of CEPTA/ICMBio, located in municipality of Pirassununga, SP, Brazil ( $21^{\circ} 55^{\prime} 55^{\prime \prime} \mathrm{S}$ and $\left.47^{\circ} 22^{\prime} 37^{\prime \prime} \mathrm{W}\right)$. One of the lagoons was fed by a spring located outside the study area. The second lagoon was created in 1983 to feed the first lagoon, and has its own spring, which is linked to the first lagoon. Because of this link, the lagoons can be considered a single water body. Fish were collected monthly from February 2008 to March 2009, alternating between the two lagoons, making a total of seven collections. Blood collection and hematological analysis were performed at the Continental Fish Hematology Laboratory (CEPTA/ICMBio). Severing the spinal cord behind the head by pitching is an effective method of killing some fish. Following this procedure, the fish were necropsied to analyze parasites on their gills. The procedures employed in this study were approved by the Ethics Committee for the Use of Animals of UNICAMP-CEUA-No1477-1. A voucher specimen was catalogued in a scientific collection at the Zoology Museum of the State University of Campinas - UNICAMP.

After the fish were weighed and measured, $3 \mathrm{~mL}$ of blood was collected from the caudal vein of each fish, using a syringe containing heparin 25,000 Ul/5mL. Blood samples were used to determine hematocrit and hemoglobin concentration levels, using the methods developed by Collier (1944) and Goldenfarb et al. (1971), respectively. The erythrocyte (Er) count was performed by the indirect method (DACIE; LEWIS, 2007). The hemoglobin concentration $(\mathrm{Hb})$ was determined by the cyanomethemoglobin method and microhematocrit (Hct) by blood centrifugation of the total volume of blood $(5 \mathrm{~min} / 12,000 \mathrm{rpm})$ in capillary tubes. The erythrocyte indices, i.e., mean corpuscular volume (MCV); mean corpuscular hemoglobin $(\mathrm{MCH})$ and mean corpuscular hemoglobin concentration (MCHC) were calculated according to Dacie and Lewis (2007).

The leucocytes and white blood cells counts were performed using blood smears stained by May-Grunwald-Giemsa, according to the methods described by Dacie and Lewis (2007). Blood extensions were photographed using a Zeiss Axioplan2 photomicroscope equipped with Leica IM50 software.

Using this quantification methodology, it was possible to count the number of leucocytes, thrombocytes, and approximately 2,000 erythrocytes in each extension. The total number of leucocytes and thrombocytes was estimated from the proportion of total erythrocytes (using a Neubauer chamber), according to Hrubec and Smith (1998).

Temperature, $\mathrm{pH}$, total dissolved solids (TDS) and conductivity were analyzed using multisensory equipment.

The gills were removed and placed in jars containing formalin 1:4,000 for subsequent collection of Monogenea. The collected Monogenea were fixed in formalin $4 \%$, then stained according to Humason (1979) and mounted in Canada Balsamto study their internal structures and organs. Other specimens were clarified, and the sclerotized structures were analyzed as described by Humason (1979).

Prevalence, mean intensity and parasite abundance values were calculated according to Bush et al. (1997).

The blood parameters were subjected to Student's $t$-test $(P<0.05)$ for comparison of parasitized and non-parasitized fish.

The nonparametric Spearman rank correlation was used to determine the infestation intensity and the Relative Condition 
Factor $(\mathrm{Kn})$ of the fish. Pearson's correlation $(r)$ was used to observe the correlation between infestation intensity of the fish and the hematological parameters. This procedure was performed using PROC CORR (SAS INSTITUTE, 1996), considering all the Monogenea specimens regardless of genus or species. The same procedure was adopted to correlate the biometry of the fish and the frequency of Monogenea. The data were logarithmized for variation analysis and the Duncan test was applied using the PROC GLM (SAS INSTITUTE, 1996). Kn was calculated for each host, according to Gomiero and Braga (2003), using the Gnumeric 1.1 statistical program. Spearman's rank correlation was used to correlate mean intensity of infection, hematological parameters and Kn.

\section{Results}

During the collection period, the water temperature varied from 19.1 to $28.7^{\circ} \mathrm{C}\left(25.4 \pm 2.9^{\circ} \mathrm{C}\right)$, the $\mathrm{pH}$ ranged from 7.2 to $9.4(8.8 \pm 0.7)$, electric conductivity varied from 9.3 to $40.1 \mu \mathrm{S} / \mathrm{cm}$ $(20.0 \pm 10.7 \mu \mathrm{S} / \mathrm{cm})$, and TDS was between 4.5 and $11.0 \mathrm{mg} / \mathrm{L}$ $(8.0 \pm 2.6 \mathrm{mg} / \mathrm{L})$.

The total length of the 76 analyzed fish varied from 16 to $38.5 \mathrm{~cm}(25.9 \pm 5.4 \mathrm{~cm})$ and the weight varied from 45 to $640 \mathrm{~g}$ $(228.1 \pm 140.4 \mathrm{~g})$. These fish were parasitized by Monogenea of the Dactylogyridae family, Urocleidoides eremitus and Anacanthorus sp. and by one unidentified species (Table 1).

Erythrocytes, thrombocytes, and leucocytes were observed in the blood extensions of parasitized and non-parasitized $H$. malabaricus, and were counted whenever possible. The erythrocytes of the fish were elongated and elliptical cells, with a centralized nucleus. The thrombocytes were stick cells, with the nucleus occupying practically all the cytoplasm. Leucocytes have a characteristic size, shape and color that differ from other cell types.

The mean values of the blood parameters of parasitized and non-parasitized $H$. malabaricus are given in Table 2 .

Pearson's correlation indicated that there was no correlation between the blood parameters/biometry of the fish and the blood parameters/intensity of Monogenea, but that there was correlation between blood parameters and some environmental factors such as temperature, TDS and conductivity (Table 3 ).

The mean Kn of the $H$. malabaricus specimens was 1.01 , indicating healthy conditions in the studied lagoons. Only one positive correlation was found between $\mathrm{Kn}$ and thrombocytes (Table 4).

\section{Discussion}

Hoplias malabaricus is a species that lives in the lower depths of lentic water with abundant aquatic vegetation, and this species is tolerant to low concentrations of dissolved oxygen (TAPHORN, 1992); SHIBATTA et al., 2002). Therefore, it can be assumed that the environmental conditions in which "traira" are found are also preferred by the parasites that cohabit with it. A recent study by Madi and Ueta (2009) demonstrated that Ancyrocephalinae (Monogenea: Dactylogyridae), a parasite of Geophagus brasiliensis, can serve as an environmental indicator. However, the authors reported higher mean intensity values than in this study.

The $H$. malabaricus specimens taken from the lagoons in Pirassununga, SP, Brazil showed similar hematocrit and erythrocyte values as those described by Paiva et al. (2000b) for Prochilodus lineatus and Schizodon borellii taken from the Paraná River and parasitized by Dactylogyridae and Cucullanus pinnai, although hemoglobin, MCV and MCHC concentrations were higher than

Table 1. Parasitic indexes of $H$. malabaricus by monogenean collected on the period from February 2008 to March 2009, from Pirassununga lagoons, São Paulo State.

\begin{tabular}{lcccc}
\hline \multicolumn{1}{c}{ Monogenean } & Analyzed Fishes (n) & Parasitized fishes & Prevalence (\%) & Mean Intensity \\
\hline Dactylogyridae* $^{*}$ & 76 & 33 & 43.4 & 33.1 \\
Urocleidoides eremitus & 76 & 33 & 43.4 & 35.5 \\
Anacanthorus sp.* & 76 & 6 & 7.8 & 37.6 \\
\hline
\end{tabular}

${ }^{*}$ No identified species.

Table 2. Variation amplitude $(\mathrm{Ax})$, mean $(\bar{x})$ and Standard Deviation $(s)$ of the blood parameters of $H$. malabaricus parasitized and non parasitized, collected on the period February 2008 to March 2009, from Pirassununga lagoons São Paulo State.

\begin{tabular}{|c|c|c|c|c|c|c|}
\hline \multirow[t]{2}{*}{ Parameters } & \multicolumn{3}{|c|}{ Parasitized fishes $(n=72)$} & \multicolumn{3}{|c|}{ Non parasitized fishes $(n=4)$} \\
\hline & $\mathbf{A x}$ & $\bar{x} \pm S$ & $p$ & $\mathbf{A x}$ & $\bar{x} \pm S$ & $p$ \\
\hline Hct (\%) & $8-75$ & $29.61 \pm 13.44$ & $<0.0001$ & $26-63$ & $37.75 \pm 17.17$ & $<0.0001$ \\
\hline $\operatorname{Er}\left(10^{6} \mu \mathrm{L}\right)$ & $1.57-3.23$ & $2.65 \pm 0.39$ & 0.028 & $2.2-3.02$ & $2.71 \pm 0.36$ & 0.015 \\
\hline $\mathrm{Lc}(\mathrm{t})(\mu \mathrm{L})$ & $6460-74400$ & $32953 \pm 16894$ & 0.123 & $15150-59400$ & $32072.5 \pm 19475.6$ & 0.353 \\
\hline $\mathrm{Tb}(\mu \mathrm{L})$ & $2960-56840$ & $15633 \pm 10961$ & 0.982 & $5800-27300$ & $15155 \pm 9023.82$ & 0.005 \\
\hline $\mathrm{Hb}(\mathrm{g} / \mathrm{dL})$ & $2.14-2.73$ & $2.32 \pm 0.09$ & 0.074 & $2.21-2.43$ & $2.29 \pm 0.09$ & 0.083 \\
\hline $\operatorname{MCV}(\mathrm{fl})$ & $28.99-388.60$ & $116.78 \pm 64.94$ & $<0.0001$ & $95.23-286.36$ & $147.68 \pm 92.78$ & $<0.0001$ \\
\hline $\mathrm{MCH}(\mathrm{pg})$ & $6.85-14.74$ & $8.99 \pm 1.67$ & 0.173 & $7.62-10.16$ & $8.55 \pm 1.11$ & 0.007 \\
\hline $\mathrm{MCCH}(\%)$ & $2.99-31.98$ & $9.33 \pm 4.16$ & 0.287 & $3.55-8.78$ & $6.84 \pm 2.29$ & 0.035 \\
\hline
\end{tabular}

Hct= Hematocrit; Er= Erithrocity; $\mathrm{Lc}_{(\mathrm{t})}=$ Total leucocytes; $\mathrm{Tb}=$ Trombocity; Hb= Hemoglobin; Mean Corpuscular Volume (MCV); Mean Cellular Hemoglobin $(\mathrm{MCH})$; Mean Concentration of Cellular Hemoglobin $(\mathrm{MCCH})$. Statistically differ between parasitized and non parasitized by $t$ test $(P<0.05)$. 
Table 3. Correlation values $(r)$ between the environmental parameters and the hematological parameters of $H$. malabaricus parasitized collected on the period February 2008 to March 2009, from Pirassununga lagoons São Paulo State.

\begin{tabular}{|c|c|c|c|c|c|c|c|c|c|}
\hline Eritrogram & $\overline{\bar{x}} \pm S$ & $\begin{array}{c}\mathrm{pH} \\
r_{\mathrm{s}}\end{array}$ & $p$ & $\begin{array}{c}\text { Temperature } \\
r_{s}\end{array}$ & $p$ & $\begin{array}{c}\text { TDS } \\
r_{\mathrm{s}}\end{array}$ & $p$ & $\begin{array}{c}\text { Conductivity } \\
r_{s}\end{array}$ & $p$ \\
\hline Hct (\%) & $29.61 \pm 13.44$ & 0.19 & 0.09 & -0.48 & $<0.0001$ & 0.45 & $<0.0001$ & 0.50 & $<0.0001$ \\
\hline $\operatorname{Er}\left(10^{6} \mu \mathrm{L}\right)$ & $2.65 \pm 0.39$ & 0.24 & 0.03 & 0.36 & 0.001 & -0.34 & 0.002 & -0.44 & $<0.0001$ \\
\hline $\mathrm{Lc}(\mathrm{t})(\mu \mathrm{L})$ & $32,953 \pm 16,894$ & -0.10 & 0.37 & -0.20 & 0.07 & 0.06 & 0.58 & 0.21 & 0.05 \\
\hline $\mathrm{Tb}(\mu \mathrm{L})$ & $15,633 \pm 10,961$ & -0.10 & 0.36 & -0.26 & 0.02 & 0.49 & $<0.0001$ & 0.37 & 0.001 \\
\hline $\mathrm{Hb}(\mathrm{g} / \mathrm{dL})$ & $2.32 \pm 0.09$ & 0.07 & 0.52 & -0.08 & 0.44 & 0.11 & 0.30 & 0.01 & 0.94 \\
\hline $\operatorname{MCV}(f)$ & $116.78 \pm 64.94$ & -0.24 & 0.03 & -0.52 & $<0.0001$ & 0.47 & $<0.0001$ & 0.55 & $<0.0001$ \\
\hline MCH (pg) & $8.99 \pm 1.67$ & -0.26 & 0.02 & -0.40 & 0.001 & 0.33 & 0.003 & 0.43 & $<0.0001$ \\
\hline MCCH (\%) & $9.33 \pm 4.16$ & 0.17 & 0.12 & 0.32 & 0.05 & -0.37 & 0.001 & -0.39 & 0.01 \\
\hline
\end{tabular}

Hct= Hematocrit; Er= Erithrocity; Lc (t)= Total leucocytes; Tb= Trombocity; Hb= Hemoglobin; Mean Corpuscular Volume (MCV); Mean Cellular Hemoglobin $(\mathrm{MCH})$; Mean Concentration of Cellular Hemoglobin $(\mathrm{MCCH})$.

Table 4. Spearman rank correlation $\left(r_{s}\right)$ between the Relative Condition Factor $(\mathrm{Kn})$ and the hematological parameters of H. malabaricus collected on the period February 2008 to March 2009, from Pirassununga lagoons Sáo Paulo State.

\begin{tabular}{lccr}
\hline \multicolumn{1}{c}{ Eritrogram } & $\overline{\boldsymbol{x}}_{ \pm} \boldsymbol{S}$ & \multicolumn{1}{c}{$\boldsymbol{r}_{\mathrm{s}}$} & \multicolumn{1}{c}{$\boldsymbol{p}$} \\
\hline $\mathrm{Hct}(\%)$ & $29.61 \pm 13.44$ & 0.01 & 0.89 \\
$\mathrm{Er}\left(10^{6} \mu \mathrm{L}\right)$ & $2.65 \pm 0.39$ & -0.18 & $\leq 0.01$ \\
$\mathrm{~Tb}(\mu \mathrm{L})$ & $15,633 \pm 10,961$ & 0.29 & $\leq 0.01$ \\
$\mathrm{MCV}(\mathrm{fl})$ & $116.78 \pm 64.94$ & 0.09 & 0.40 \\
$\mathrm{MCCH}(\%)$ & $9.33 \pm 4.16$ & 0.01 & 0.92
\end{tabular}

Hct= Hematocrit; Er= Erythrocyte count; $\mathrm{Tb}=$ Thrombocyte count; Mean Corpuscular Volume (MCV); Mean Concentration of Cellular Hemoglobin $(\mathrm{MCCH})$

in this study. These differences can probably be ascribed to the feeding habitat and physiology of these fish.

Studies have demonstrated that hematological parameters such as Hct, MCV and MCH may indicate alterations in water quality (VAN VUREN, 1986), particularly with regard to temperature, TDS, conductivity and dissolved oxygen.

The parasitized and non-parasitized fish showed no significant difference in hematological data, but a higher number of erythrocytes and hematocrit level was found in the parasitized animals. However, this slight increase differs from that reported by Montero et al. (2004). It also differs from the results reported by Paiva and Tavares-Dias (2002) for the marine fish Mugil platanus infected by Trichodina, Monogenea, Copepodes and Hirudinea, probably because this fish species was infested by parasites other than Monogenea and lived in an estuary region.

In the present study, the number of erythrocytes and conductivity were negatively correlated, reinforcing the belief that erythrocytes may be bioindicators of environmental stress (PAIVA et al., 2000a).

The function of thrombocyte cells in fish is still controversial (TAVARES-DIAS; MORAES, 2004). These cells are characteristic of birds, reptiles, amphibians and fish, and their role in blood coagulation is well described. Albeit not of the leukocyte cell lineage, the participation in inflammatory exudates and the phagocytic function of these cells have been studied extensively, and their role in the organic defense of different of animal species has been reported (DIAS; SINHORINI, 1991; MATUSHIMA; MARIANO, 1996).
Leucocytes and thrombocytes have therefore been placed in a single group and designated as blood cells for organic defense (TAVARES-DIAS et al., 1998a, b). The literature reports that the average number of total thrombocytes in freshwater teleosts may vary from 2,000 to $68,400 \mu \mathrm{L}$ of blood (UEDA et al., 1997), while in $H$. malabaricus the number varies from 28,200 to $76,000 \mu \mathrm{L}$ of blood (TAVARES-DIAS; MORAES, 2004). The number of thrombocytes found in the present study varied from 2,960 to $56,840 \mu \mathrm{L}$ of blood in parasitized fish and from 5,800 to $27,300 \mu \mathrm{L}$ of blood in non- parasitized fish, which is consistent with previous studies and correlated with TDS (Table 3). However, other than this correlation, the number of thrombocytes was uncorrelated with the Monogenea infestation, confirming the absence of pathogenicity.

Parasitism by Monogenea is common in fish in natural environments, and is rarely fatal when abundance is controlled by the host's immune system (TAVARES-DIAS; MORAES, 2004). Knowledge about the host-parasite relationship and the physiological condition of fish may be helpful in controlling these parasites through the application of fish breeding methods, although the occurrence of those parasites is inevitable and may sometimes result in serious pathology.

Many parasites can live on the host without causing any damage (THATCHER, 1981). In the present study, ectoparasitism by Monogenea did not alter the hematological parameters of $H$. malabaricus. This is most likely due to the equilibrium between host and parasite. However, this equilibrium can be modified by any change in water quality and/or by rapid temperature fluctuations (PAIVA et al., 1997). The results of the present study were similar to those reported by Paiva et al. (1997) for Mugil platanus parasitized by Monogenea. On the other hand, Rio-Zaragoza et al. (2010) did not find a hematological response in Lutjanus guttatus, Steindachner (1869) experimentally infected with Dactylogyridae, which showed an elevated number of erythrocytes and thrombocytes. At the three levels of infection, all the erythrocyte parameters (Hct; $\mathrm{Hb}$; MCV and MCHC) were increased when compared to the control group.

The analysis of Kn variations between populations and individuals may be used to demonstrate a biological characteristic, such as environmental quality and the availability of feeding resources (BOLGER; CONNOLLY, 1989), and also of the parasite species on their hosts in a natural environment (PAIVA et al., 
2000a) or in confinement (TAVARES-DIAS et al., 2002). In the host-parasite relationship, it is common to observe a negative correlation between $\mathrm{Kn}$ and levels of parasitism. However, Lizama et al. (2004) observed a positive correlation between Kn and the abundance of some parasite species infesting Prochilodus lineatus, suggesting that larger fish with a higher Kn value can withstand higher levels of parasitism. The results of the present study corroborate this finding.

It was expected that a higher level of infestation would elicit a stress response in the host, which would be observable in its hematological parameters. However, the results of the present study demonstrated that a high intensity of monogenean infestation is apparently not reflected in hematological parameters, nor does it cause stress in parasitized fish, which could lead to the development of pathology. The present study provides useful information for the evaluation of fish physiology and the determination of ideal conditions for breeding in captivity.

Hematological parameters were found to be highly sensitive to environmental parameters, particularly with respect to the presence of Monogenea in the natural environment.

\section{Taxonomic Summary}

Host: Hoplias malabaricus Bloch (1794); Specimen deposited: (ZUEC-PIS 7302)

Parasites: Monogenea: Urocleidoides sp.; Specimen deposited: (ZUEC-PLA 22); Monogenea: Urocleidoides eremitus (Kritsky, Thatcher \& Boeger, 1986); Specimen deposited: (ZUEC-PLA 23); Monogenea: Anacanthorus sp.; Specimen deposited: (ZUEC-PLA 24)

Location: Pirassununga, SP, Brazil $\left(21^{\circ} 55^{\prime} 55^{\prime \prime} \mathrm{S}\right.$ and $\left.47^{\circ} 22^{\prime} 37^{\prime \prime} \mathrm{W}\right)$

\section{Site of infestation: Gill.}

\section{Acknowledgements}

The authors are indebted to Mr. Ricardo Afonso Torres de Oliveira, from ICMBio (Chico Mendes Institute for Biodiversity Conservation) for his assistance, to Dr. Maria de los Angeles Perez Lizama, from Nupélia (Limnology, Ichthyology and Aquaculture Research Center) for her analysis and interpretation of the Condition Factor, and to Professor Dr. Arício Xavier Linhares for his statistical analysis. The author gratefully acknowledges PROCAD (National Program of Academic Cooperation, Brazil) for its financial support of this research.

\section{References}

Ballarin L, Dall'Oro M, Bertotto D, Libertini A, Francescon A, Barbaro A. Haematological parameters in Umbrina cirrosa (Teleostei, Sciaenidae): a comparison between diploid and triploid specimens. Comp Biochem Physiol A Mol Integr Physiol 2004; 138(1): 45-51. PMid:15165570. http://dx.doi.org/10.1016/j.cbpb.2004.02.019

Bolger T, Connolly PL. The selection of suitable indices for the measurement and analysis of fish condition. J Fish Biol 1989; 34(2): 171182. http://dx.doi.org/10.1111/j.1095-8649.1989.tb03300.x

Bush AO, Lafferty KD, Lotz JM, Shostak AW. Parasitology meets ecology on its own terms: Margolis et al. revisited. J Parasitol 1997; 83(4): 575583. PMid:9267395. http://dx.doi.org/10.2307/3284227
Corrêa LL, Karling LC, Takemoto RM, Ceccarelli PS, Ueta MT. Hematological alterations caused by high intensity of $\mathrm{L}_{3}$ larvae of Contracaecum sp Railliet \& Henry, 1912 (Nematoda, Anisakidae) in the stomach of Hoplias malabaricus in lakes in Pirassununga, São Paulo. Parasitol Res 2013; 112(8): 2783-2789. PMid:23666228. http://dx.doi. org/10.1007/s00436-013-3446-8

Collier HB. The standardization of blood haemoglobin determinations. Can Med Assoc J 1944; 50(6): 550-552. PMid:20323122 PMCid:PMC1581573.

Dacie JV, Lewis SM. Practical haematology. 7th ed. London: Churchill Livingstone; 2007.

Dias JLC, Sinhorini IL. Qualitative evaluation of the inflammatory response modulated by temperature in tadpoles of Rana catesbeiana. Cienc Cult 1991; 43(4): 304-306.

Goldenfarb PB, Bowyer FP, Hall E, Brosious E. Reproducibility in the hematology laboratory: the microhematocrit determination. Am J Clin Pathol 1971; 56(1): 35-39. PMid:5556212.

Gomiero LM, Braga FMS. Relação peso-comprimento e fator de condição para Cichla cf. ocellaris e Cichla monoculus (Perciformes, Cichlidae) no reservatório de Volta Grande, rio Grande - MG/SP. Acta Sci Biol Sci 2003; 25(1):79-86. http://dx.doi.org/10.4025/actascibiolsci. v25i1.2119

Graham MS, Haedrich RL, Fletcher GL. Hematology of three deepsea fishes: A reflection of low metabolic rates. Comp Biochem Physiol A Comp Physiol 1985; 80(1): 79-84. http://dx.doi.org/10.1016/03009629(85)90682-6

Hrubec TC, Smith SA. Hematology of fish. In: Feldman BF, Zinkl JG, Jain NC. Schalm's Veterinary Hematology. 5th ed. Sydney: W.W. Lippincott; 1998. p. 1120-1125.

Humason GL. Animal tissue techniques. 4th ed. San Francisco: W.H. Freeman and Company; 1979.

Khan RA, Thulin J. Influence of pollution on parasites of aquatic animals. Adv Parasitol 1991; 30: 201-238. http://dx.doi.org/10.1016/ S0065-308X(08)60309-7

Khan RA. Health of flatfish from localities in Placentia Bay, Newfoundland, contaminated with petroleum and PCBs. Arch Environ Contam Toxicol 2003; 44(4): 485-492. PMid:12712279. http://dx.doi. org/10.1007/s00244-002-2063-9

Kohn A, Fernandes BMM, Cohen SC. South american trematodes parasites of fishes. Rio de Janeiro: Fiocruz; 2007.

Lizama MAP, Takemoto RM, Pavanelli GC. New species of Tereancistrum Kritsky, Thatcher \& Kayton, 1980 (Monogenea: Dactylogyridae: Ancyrocephalinae) from the gills of Prochilodus lineatus (Osteichthyes: Prochilodontidae) from the upper Paraná River floodplain, Brazil. Syst Parasitol 2004; 57(1): 45-49. PMid:14739674. http://dx.doi. org/10.1023/B:SYPA.0000010684.67784.6e

Mackenzie K, Williams HH, Williams B, McVicar AH, Siddall R. Parasites as indicators of water quality and the potential use of helminth transmission in marine pollution studies. Adv Parasitol 1995; 35: 85-144. http://dx.doi.org/10.1016/S0065-308X(08)60070-6

MacKenzie K. Parasites as pollution indicators in marine ecosystems: a proposed early warning system. Mar Pollut Bull 1999; 38(11): 955-959. http://dx.doi.org/10.1016/S0025-326X(99)00100-9

Madi RR, Ueta MT. O papel de Ancyrocephalinae (Monogenea: Dactylogyridae), parasito de Geophagus brasiliensis (Pisces: Cichlidae), 
como indicador ambiental. Rev Bras Parasitol Vet 2009; 18(2): 38-41. http://dx.doi.org/10.4322/rbpv.01802008

Matushima ER, Mariano M. Kinetics of the inflammatory reaction induced by carrageenin in the swinbladder of Oreochromis niloticus (Nile tilapia). Braz J Vet Res Anim Sci 1996; 33(1): 5-10.

Montero FE, Crespo S, Padrós F, Gándara F, García A, Raga JA. Effects of the gill parasite Zeuxapta seriolae (Monogenea: Heteraxinidae) on the amberjack Seriola dumerili Risso (Teleostei: Carangidae). Aquaculture 2004; 232(1-4): 153-163. http://dx.doi.org/10.1016/ S0044-8486(03)00536-2

Moles A, Wade TL. Parasitism and phagocytic function among sand lance Ammodytes hexapterus Pallas exposed to crude oil-laden sediments. Bull Environ Contam Toxicol 2001; 66(4): 528-535. http://dx.doi. org/10.1007/s00128-001-0039-5

Nakatani K, Agostinho AA, Baumgartner G, Bialetzki A, Sanches PV, Makrakis MC, et al. Ordem Characiformes. In: Ovos e Larvas de Peixes de Água Doce: Desenvolvimento e Manual de Identificação. Maringá: UEM; 2001. p. 73-220.

Paiva MJTR, Ishikawa CM, Campos BES, Eiras AC. Haematological characteristics associated with parasitism in mullets, Mugil platanus Günther, from the estuarine region of Cananéia, São Paulo, Brazil. Rev Bras Zool 1997; 14(2): 329-339. http://dx.doi.org/10.1590/S010181751997000200007

Paiva MJTR, Ishikawa CM, Eiras AA, Felizardo NN. Haemotological analysis of Chara, Pseudoplatystoma fasciatum in captivity. Aqua 2000 Responsible aquaculture in the new millennium. Nice, France. May 2-6 2000. Eur Aquacult Soc 2000a; 28: 590. Special Publication.

Paiva MJTR, Souza ATS, Pavanelli GC, Takemoto RM, Eiras AC. Hematological evaluation in commercial fish species from the floodplin of the upper Paraná River, Brazil. Acta Sci Biol Sci 2000b; 22(2): 507-513.

Paiva MJTR, Tavares-Dias M. Eritrograma, relação viscerosomática, hepatosomática e esplenosomática em tainhas Mugil platanus Günther (Osteichthyes, Mugilidae) parasitadas. Rev Bras Zool 2002; 19(3): $807-$ 818. http://dx.doi.org/10.1590/S0101-81752002000300019

Rio-Zaragoza OB, Avila EJF, Rueda PA. Haematological and gill responses to an experimental infection of Dactylogyrid monogeneans on the spotted rose snapper Lutjanus guttatus (Steidachner, 1869). Aquacult Res 2010; 41(11): 1592-1601. http://dx.doi.org/10.1111/j.13652109.2009.02471.x

Rosim DF, Mendoza-Franco EF, Luque JL. New and previously described species of Urocleidoides (Monogenoidea: Dactylogyridae) infecting the gills and nasal cavities of Hoplias malabaricus (Characiformes: Erythrinidae) from Brazil. J Parasitol 2011; 97(3): 406-417. PMid:21506767. http:// dx.doi.org/10.1645/GE-2593.1

Shibatta OA, Orsi ML, Bennemann ST, Silva-Souza AT. Diversidade e distribuiçáo de peixes na bacia do rio Tibagi. In: Medri ME, Bianchini E, Shibatta OA, Pimenta JA, editores. A bacia do rio Tibagi. Londrina: EDUEL; 2002. p. 403-423.

Silvano RAM, Oyakawa OT, Amaral BD, Begossi A. Peixes do alto rio Juruá (Amazônia, Brasil). São Paulo: Universidade de São Paulo, Imprensa Oficial do Estado de Paulo; 2001. PMid:11677442.
Statistical Analisys System Institute - SAS. SAS User's Guide: Statistcs. Release 6.12. North Caroline: Cory; 1996.

Taphorn DC. The characiform fishes of the Apure River drainage, Venezuela. Guanare: BioLlania- Edición Especial; 1992. Monografias Cientificas del Museo de Ciencias Naturales.

Tavares-Dias M, Sandrim EFS, Sandrim A. Características hematológicas do tambaqui (Colossoma macropomum) Cuvier, 1818 (Osteichthyes: Characidae) em sistema de monocultivo intensivo. I. Série Eritrocitária. Rev Bras Biol 1998a; 58(2): 197-202.

Tavares-Dias M, Sandrim EFS, Sandrim A. Características hematológicas do tambaqui (Colossoma macropomum) Cuvier, 1818 (Osteichthyes: Characidae) em sistema de monocultivo intensivo. I. Série Eritrocitária. Rev Bras Biol 1998b; 58 (2):197-202.

Tavares-Dias M, Martins ML, Kronka SN. Evaluation of the haematological parameters in Piaractus mesopotamicus Holmberg (Osteichthyes: Characidae) with Argulus sp. (Crustacea, Branchiura) infestation and treatment with organophosphate. Rev Bras Zool. 1999a; 16(2): 553-555. http://dx.doi.org/10.1590/S0101-81751999000200019

Tavares-Dias M, Schalch SHC, Martins ML. Hematologia de teleósteos brasileiros com infecção parasitária. I. Variáveis do Leporinus macrocephalus Garavello \& Britski, 1988 (Anostomidae) e Piaractus mesopotamicus Holmberg, 1887 (Characidae). Acta Sci Biol Sci 1999b; 21(2): 337-342.

Tavares-Dias M, Moraes FR, Martins ML, Santana AE. Haematological changes in Oreochromis niloticus (Osteichthyes: Cichlidae) with gill ichthyophthiriasis and saprolegniosis. Bol Inst Pesca 2002; 28(1): 1-9.

Tavares-Dias M, Moraes FR. Hematologia de peixes teleósteos. Ribeirão Preto: Villimpress; 2004.

Tavares-Dias M, Moraes FR. Leukocyte and thrombocyte reference values for channel catfish (Ictalurus punctatus Raf.), with an assessment of morphologic, cytochemical, and ultrastructural features. Vet Clin Pathol 2007; 36(1): 49-54. PMid:17311194. http://dx.doi.org/10.1111/ j.1939-165X.2007.tb00181.x

Thatcher VE. Patologia de peixes da Amazônia brasileira. Aspectos gerais. Acta Amaz 1981; 11(1): 125-140.

Ueda IK, Egami MI, Sasso WS, Matushima ER. Estudos hematológicos em Oreochromis niloticus (Linnaeus, 1758) (Cichilidae, Teleostei)- Parte I. BrazJ Vet Res Anim Sci 1997; 34(5): 270-275.

Van Vuren JHJ. The effects of toxicants on the haematology of Labeo umbratus (Teleostei: Cyprinidae). Comp Biochem Physiol C 1986; 83(1): 155-159. http://dx.doi.org/10.1016/07428413(86)90029-0

Viljoen BCS, Van Vuren JHJ. Physical characteristics of the blood plasma of Labeo ruddi and Labeo rosae (Pisces: Cyprinidae). Comp Biochem Physiol A Comp Physiol 1991; 100(4): 873-875.

Wells RMG, Baldwin J, Seymour RS, Christian K, Brittain T. Red blood cell function and haematology in two tropical freshwater fishes from Australia. Comp Biochem Physiol A Mol Integr Physiol 2005; 141(1): $87-$ 93. PMid:15893948. http://dx.doi.org/10.1016/j.cbpb.2005.04.005 